\title{
The Influence of Professional Skepticism, Independence, Competence, and Experience on Auditor's Ability to Detect Fraud
}

\author{
Armanto Witjaksono* and Yudistira Yudatama \\ Accounting Department, Bina Nusantara University, Binus University, Jalan Kebon Jeruk Raya No.27, Kebon \\ Jeruk, Jakarta Barat Indonesia \\ *Corresponding authoremail: armanto@binus.ac.id
}

\begin{abstract}
This study aims to determine the effect of professional skepticism, independence, competence, and experience on the ability of auditors to detect fraud. The design of this research is causality research or causal relationship. The sample used in this study amounted to 74 respondents who work as auditors at public accounting firms, with the sampling technique is purposive sampling. The data analysis method used is multiple linear regression analysis. The results showed that there was a positive influence on professional skepticism, competence and experience on the ability of auditors to detect fraud. However, the independence of the auditor's ability to detect fraud has a negative effect. The conclusion that can be drawn from this study is that competence is the most necessary thing so that auditors can detect whether there is fraud quickly and accurately.
\end{abstract}

Keywords: Proffesional Skepticism, Independence, Auditor

\section{INTRODUCTION}

The development of the need for financial statements that have been audited by external auditors has now experienced a fairly large and significant development. External audits are needed to improve company performance in order to gain greater credibility in the eyes of the public and investors, and are used to provide sufficient assurance to interested parties that the financial statements presented by company management are free from material misstatement and have been prepared in accordance with established standards. apply [1].

The failure of auditors to detect fraud (fraud) is proven by the existence of several cases involving public accountants. Currently, the practice of fraud (fraud) is increasingly occurring in various ways that continue to develop, so that auditors are required to improve their ability to detect fraud. The auditor's ability to detect fraud is the quality of an auditor in explaining the lack of fairness of the financial statements presented by identifying and proving the fraud [2] Each auditor certainly has different abilities in detecting fraud caused by several factors, including different auditors' skepticism, independence, competence, and the level of experience of the auditors themselves

\section{LITERATURE REVIEW 2.1 Professional Skepticism}

Professional skepticism is an attitude that includes a mind that is always asking questions (questioning mind), alert (alert), to conditions and circumstances that indicate the possibility of material misstatement caused by intentional or error and critical assessment (assessment) of audit evidence. (International Federation of Accountants (IFAC) in [3]. Based on this understanding, it can be concluded that professional skepticism is a critical attitude and does not easily believe in an auditor about the existing evidence. The auditor must take this attitude in order to produce a quality audit report, so that the report used can express an actual opinion (opinion) for the parties who have an interest in the audit report.

\section{H1: It is suspected that there is a significant positive effect Professional Skepticism on the Auditor's Ability to Detect Fraud}

\subsection{Auditor Independence}

Independence means a mental attitude that is free from influence, not controlled by other parties, not dependent on others. Independence also means the existence of honesty within the auditor in considering facts and the existence of impartial objective considerations within the auditor in formulating and expressing his opinion [4]. So it can be concluded that independence is the attitude of an auditor who is free from influence and impartial (neutral) to anyone and is objective in providing an 
opinion (opinion) towards clients. Auditors must be honest, free from obligations towards their clients, and have no interest with clients.

H2: It is suspected that there is a significant positive effect Auditor Independence on Auditor Ability to Detect Fraud

\subsection{Auditor Competence}

Competence is a must for an auditor to have a formal education in auditing and accounting, adequate practical experience for the work being carried out, and attend continuing professional education [5]

H3: It is suspected that there is a significant positive effect Auditor's Competence on Auditor's Ability to Detect Fraud

\subsection{Audit Experience}

According to [6] audit experience is experience in auditing financial statements in terms of both the length of time and the number of assignments that have been handled. Whereas the more audit experience an auditor has, the more assumptions can be made in explaining audit findings.

H4: It is suspected that there is a significant positive effect Audit Experience on the Auditor's Ability to Detect Fraud

\subsection{Ability to Detect Fraud (Fraud)}

[7] explains that the ability to detect fraud is an effort to get sufficient initial indications of fraud, while at the same time narrowing the space for the perpetrators of fraud. Meanwhile, according to [2] the auditor's ability to detect fraud is the quality of an auditor in explaining the impropriety of the financial statements presented by the company by identifying and proving fraud.

H5: It is suspected that there is a significant influence on professional skepticism, auditor independence, auditor competence, and audit experience together on the ability of auditors to detect fraud

\subsection{The Effect of Professional Skeptism on} the Auditor's Ability to Detect Fraud

H6: It is suspected that there is a significant positive effect Professional Skepticism on the Auditor's Ability to Detect Fraud.

\section{RESEARCH METHODS}

The population in this study were all auditors of the Jakarta Public Accountant Firm registered with IAPI in 2018.
TABLE 1. Research population

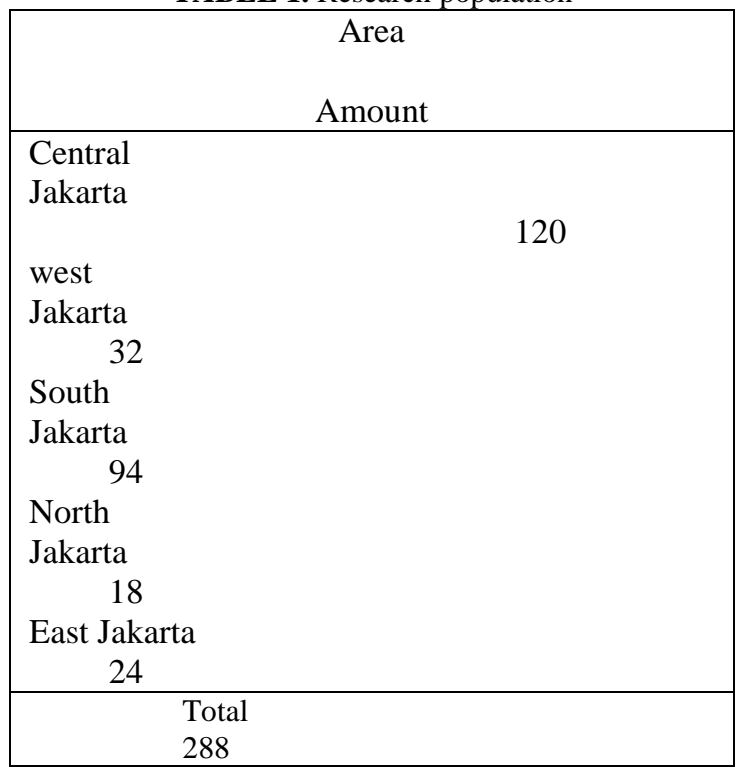

The sampling technique used in this study was purposive sampling technique.The criteria used in sample selection are:

a. Auditor who has at least 3 years work experience.

b. Auditor who has a position as a senior auditor, supervisor (SPV), manager, and partner.

Using Slovin Formula with tolerable error rate of 10 percent, we collected 74 Auditors from the population as samples. To those auditors we send questionnaires, and analyze the results.

$Y=\alpha+\beta_{1} S P+\beta_{2} I A+\beta_{3} K A+$ $\beta_{4} P A+e$

Information:

Fraud (Fraud)

$\alpha \quad=$ Constant

$\beta_{1}, \beta_{2}, \beta_{3}, \beta_{4} \quad=$ Regression coefficient

SP $\quad=$ Professional Skepticism

IA = Auditor Independence

KA = Auditor Competence

PA = Audit Experience

e $=$ standard error / error 


\section{RESULTS AND DISSCUSION}

\subsection{The descriptive Statistic of results as below:}

TABLE 2. Descriptive Statistics Test Result

\begin{tabular}{|c|c|c|c|c|c|}
\hline \multicolumn{7}{|c|}{} \\
\hline Var & $\mathrm{N}$ & Minimum & Maximum & Mean & Std.Deviation \\
\hline Skepticism & 74 & 27 & 55 & 43.5270 & 5.53995 \\
\hline Independence & 74 & 14 & 29 & 23.1892 & 2.93620 \\
\hline Competence & 74 & 26 & 45 & 33.4865 & 4.69696 \\
\hline Experince & 74 & 19 & 40 & 30.2297 & 5.11390 \\
\hline $\begin{array}{c}\text { Fraud Detection } \\
\text { Ability }\end{array}$ & 74 & 17 & 37 & 26.7297 & 5.15857 \\
\hline
\end{tabular}

a. The variable of professional skepticism with a total of 74 auditors as respondents, has an average value (mean) of 43.52 or an average of 3.70. This average value explains that the professional skepticism possessed by an auditor is quite high, which means that the auditors who are respondents in this study have an alert attitude (alert) to conditions and circumstances that indicate the possibility of material misstatement due to intentionality

b. The auditor independence variable with a total of 74 auditors as respondents, has an average value (mean) of 23.18 or an average of 3.92 . This average value reflects high auditor independence, meaning that the auditors who are respondents in this study have an attitude of being free from influence and impartial (neutral) to anyone and being objective in giving opinions (opinions) to clients.

c. The auditor competence variable with a total of 74 auditors as respondents, has an average value of 33.48 or an average of 3.82 . So it can be concluded that the competence possessed by an auditor is high, which means that the auditors who are respondents in this study carry out their work with good quality results.

d. The audit experience variable with a total of 74 auditors as respondents, has an average (mean) value of 30.23 or an average of 3.88 . So it can be concluded that the auditors who were respondents in this study had high audit experience, meaning that they had knowledge or expertise gained from an event through direct observation or participating in the event.

e. The variable of the auditor's ability to detect fraud with a total of 74 auditors as respondents, has an average (mean) value of 26.72 or an average of 3.48. So it can be concluded that the auditor has sufficient quality himself as an auditor to explain the lack of fairness of the financial statements presented by the company by identifying and proving the fraud.

Table 3 depict information concerning reliability of questionnaire for each variable.

TABLE 3. Reliability Test Results

\begin{tabular}{|l|c|l|l|}
\hline \multicolumn{1}{|c|}{ Var } & N & $\begin{array}{l}\text { Cronbach's } \\
\text { Alpha }\end{array}$ & Conclusion \\
\hline Skepticism & 13 & 0.696 & Realiable \\
\hline Independence & 7 & 0.714 & Realiable \\
\hline Competence & 10 & 0.755 & Realiable \\
\hline Experince & 9 & 0.621 & Realiable \\
\hline $\begin{array}{l}\text { Fraud Detection } \\
\text { Ability }\end{array}$ & 9 & 0.741 & Realiable \\
\hline
\end{tabular}

Based on Table 3, it can be informed that $t$ all questions for each variable are realiable. Then Researcher proceed with data gathering.

Classic Assumption Test, the normality test aims to test whether in the linear regression model, confounding or residual variables have a normal distribution or not. To find out that the research data is normally distributed using the Kolmogorov-Smirnov (KS). Data is declared normal if KS Probability value is 
bigger than Most Extreme Difference Value From the results above, the absolute Most Extreme Differences assessment of 0.151 , it is smaller than the KS table of 0.160 , then the data above can be said to be normal.

TABLE 4. Normality Test Results

\begin{tabular}{|l|c|c|}
\hline & & $\begin{array}{l}\text { Unstandardized } \\
\text { Residual }\end{array}$ \\
\hline $\mathrm{N}$ & Mean & 74 \\
\hline $\begin{array}{c}\text { Normal } \\
\text { parameter }^{\mathrm{a}, \mathrm{b}}\end{array}$ & Std. Deviation & 3,586 \\
\hline & Absolute & 0,151 \\
\hline $\begin{array}{c}\text { Most extreme } \\
\text { difference }\end{array}$ & Positive & 0,89 \\
\hline & Negative & $-0,151$ \\
\hline & & 0,151 \\
\hline Test statistic & & $0,000^{\mathrm{c}}$ \\
\hline $\begin{array}{c}\text { Asymp Sig.(2- } \\
\text { tailed) }\end{array}$ & & \\
\hline
\end{tabular}

From the results above, the absolute Most Extreme Differences assessment of 0.151 , it is smaller than the KS table of 0.160 , then the data above can be said to be normal.

\subsection{Multicollinearity Test}

Test of multicollinearity aims to test whether the regression model found a correlation between independent variables. The Multicollinearity said not exist if variance inflation factor (VIF) less than 10. Thus, all independent variables are free from multicollinearity (free from data collisions) because each of these variables has a tolerance value 0.1 and variance inflation factor (VIF) 10.
TABLE 5. Multicollinearity test

\begin{tabular}{|l|r|c|}
\hline \multicolumn{1}{|c|}{ Var } & Tolerance & VIF \\
\hline Skepticism & 0.689 & 1,451 \\
\hline Independence & 0.561 & 1,782 \\
\hline Competence & 0.786 & 1,272 \\
\hline Experince & 0.573 & 1,744 \\
\hline
\end{tabular}

From the results above, all questions are valid, so the entire questionnaire is used in the actual questionnaire.

\subsection{Heteroscedasticity Test}

The following are the results of the normality test that has been carried out:

Scatterplot

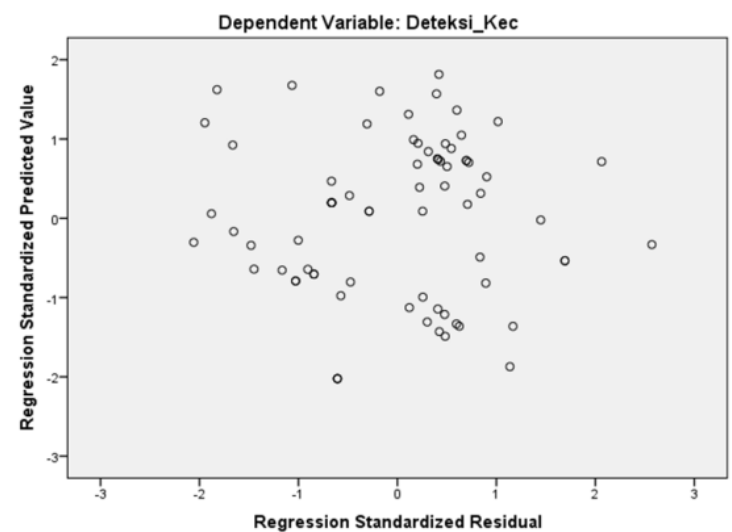

FIGURE 1. Heteroscedasticity Test Results

Based on Figure 1, it can be concluded that the plot graph shows no heteroscedasticity in the regression model. This is because the plot graph does not form a certain pattern or the points spread randomly either above or below zero on the $\mathrm{Y}$ axis.

\subsection{Hypothesis Test}

TABLE 6. Multiple linear regression analysis test

\begin{tabular}{|c|c|c|c|c|c|c|}
\hline & & \multicolumn{2}{|c|}{$\begin{array}{c}\text { Unstandardized } \\
\text { Coefficients }\end{array}$} & \multicolumn{2}{c|}{$\begin{array}{c}\text { Unstandardized } \\
\text { Coefficients }\end{array}$} & \\
\hline$\underline{\underline{M}}$ & & $\mathrm{~B}$ & Std.Error & Beta & $\mathrm{t}$ & Sig \\
\hline $\mathbf{1}$ & Constant & $-3,547$ & 4,314 & & 0,822 & 0,414 \\
\hline & $X_{1}$ & 0,253 & 0,094 & 0,272 & 2,690 & 0,009 \\
\hline & $X_{2}$ & $-0,289$ & 0,197 & $-0,165$ & $-1,472$ & 0,146 \\
\hline & $X_{3}$ & 0,504 & 0,104 & 0,459 & 4,855 & 0,000 \\
\hline & $X_{4}$ & 0,301 & 0,112 & 0,289 & 2,694 & 0,009 \\
\hline
\end{tabular}

The multiple regression equation for the three independent variables in this study is as follows:

$$
\begin{aligned}
Y=-3.547+ & 0.253 X_{1}-0.289 X_{2} \\
+ & 0.504 X_{3}+0,301 X_{4}+\varepsilon
\end{aligned}
$$


a. Hypothesis 1 Test: Based on the results of the $\mathrm{t}$ test above, it can be concluded that Hal is accepted, because the sig value 0.009 is less than 0.05

b. Hypothesis 2 Test: Based on the results of the $\mathrm{t}$ test above, it can be concluded that $\mathrm{Ha} 2$ is rejected, because the sig value 0.146 is bigger than 0.05 . c. Hypothesis 3 Test: Based on the results of the $t$ test above, it can be concluded that $\mathrm{Ha} 3$ is accepted, because the sig value 0.000 is less than 0.05 .

d. Hypothesis 4 Test: Based on the results of the $t$ test above, it can be concluded that $\mathrm{Ha} 4$ is accepted, because the sig value 0.009 is less than 0.05 .

TABLE 7. F test results (simultaneous)

\begin{tabular}{|l|c|c|c|c|c|c|}
\hline & Model & Sum of Squares & df & Mean Square & F & Sig. \\
\hline $\mathbf{1}$ & Regresion & 1000,486 & 4 & 250,121 & 18,319 & $0.000^{\text {b }}$ \\
\hline & Residual & 942,109 & 69 & 13,654 & & \\
\hline & Total & 1942,595 & 73 & & & \\
\hline
\end{tabular}

The F test aims to show whether all independent or free variables included in the model have a joint influence on the dependent variable or dependent variable [8]. In this study, the F-table value was 18.3191 with a significance level of 0.00. Based on the results of Table 7, the F-statistic value with the independent variables of Professional Skepticism, Independence, Competence, and Experience on Aditor's Ability is 29.02590 where this value is greater than the F-table value with a significance value of 0.0000 or less than the significance value of 0.05 , which means that all independent variable simultaneously affect ROA as the dependent variable.

\subsection{The Coefficient of Determination R2}

The amount of Adjusted R2 based on the results of the analysis was obtained at 0.487 . Thus the magnitude of the influence exerted by the variable Professional Skepticism, Independence, Competence, and Experience on Aditor's Ability to Detect Fraud in proving fraud is $48.7 \%$. while the remaining $51.3 \%$ is influenced by other factors not examined in this study

TABLE 8. Results of the coefficient of determination R2

\begin{tabular}{|l|c|c|c|c|}
\hline$\underline{\text { Model }}$ & $\mathrm{R}$ & $\begin{array}{c}\mathrm{R} \\
\text { Square }\end{array}$ & Adjust R Square & $\begin{array}{c}\text { Std. Error of te } \\
\text { Estimate }\end{array}$ \\
\hline 1 &, $718^{\mathrm{a}}$ &, 515 &, 487 & 3,69510 \\
\hline
\end{tabular}

Based on Table 8 , it can be seen that the variable auditor ability to detect fraud can be explained by the variables of professional skepticism, auditor independence, auditor competence, and auditing experience by $47.8 \%$. While the remaining 0.515 or $51.5 \%$ can be explained by variables other than the variables used in this study, such as professionalism, accountability, professional ethics, and so on.

\section{CONCLUSIONS AND SUGGESTIONS}

\subsection{Conclusion}

This study aims to examine the factors that affect the ability of auditors to detect fraud in auditors who work at the West Jakarta Public Accounting Firm which is registered with IAPI in 2018. The factors used in this study are Professional Skepticism,
Auditor Independence, Auditor Competence, and Audit Experience. Based on the results of the research discussion, the following conclusions were obtained:

- Professional skepticism has a positive effect on the ability of auditors to detect fraud.

- Auditor independence has no effect on the ability of auditors to detect fraud.

- Auditor competence has a positive effect on the ability of auditors to detect fraud.

- Audit experience has a positive effect on the ability of auditors to detect fraud.

- Professional skepticism, auditor independence, auditor competence, and audit experience simultaneously affect the ability of auditors to detect fraud. 


\subsection{Suggestion}

Based on the results of the research conducted, the suggestions that can be given are as follows:

- Make internal rules to limit the length of the engagement with the client company in accordance with the regulations of the Financial Services Authority.

- For Auditors, it can be lived on and improved formal education in auditing.

- For Further Research can add other variables that are thought to have an influence on the ability of auditors to detect fraud (fraud), such as professionalism, accountability, professional ethics, and so on.

\section{REFERENCES}

[1] Anggriawan, E. F. Pengaruh pengalaman kerja, skeptisme profesional dan tekanan waktu terhadap kemampuan auditor dalam mendeteksi fraud (Studi empiris pada Kantor Akuntan Publik di DIY). Nominal: Barometer Riset Akuntansi dan Manajemen, 3(2), 101-116. 2014

[2] Fitriany, H. N. Pengaruh Beban Kerja, Pengalaman Audit Dan Tipe Kepribadian Terhadap Skeptisme Profesional Dan Kemampuan Auditor Dalam Mendeteksi Kecurangan. Universitas Indonesia, Jakarta. 2012

[3] Tuanakotta, Theodorus M. Audit Berbasi ISA (International Standards on Auditing). Salemba Empat, Jakarta. 2014

[4] Mulyadi. Auditing, Edisi Kelima, Cetakan Pertama. Jakarta: Salemba Empat. 2002

[5] Arens, A. A., Beasley, M. S., \& Elder, R. Auditing and assurance services: an integrated approach (No. 657.64/A68au). 2006.

[6] Ida, Suraida. Pengaruh Etika, Kompetensi, Pengalaman Audit dan Risiko Audit terhadap Skeptisisme Profesional Auditor dan Ketepatan Pemberian Opini Akuntan Publik". Sosiohumaniora, Vol. 7 No. 3, November 2005: 186-202. 2005

[7] Valery G Kumaat. Internal Audit. Jakarta: Penerbit Erlangga. 2011

[8] Ghozali, Imam. Multivariate Analysis Application with the IBM SPSS 21 Program. Semarang: Diponegoro University Publishing Agency. 2013 